\title{
Negative Effects of Maternal Smoking on Pregnancy and the Fetus in Relation to Elevated Levels of Erythropoetin in Umbilical Cord Plasma
}

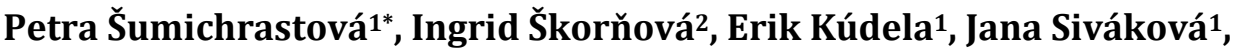 \\ Michaela Hrtánková1, Iveta Švecová1, Kamil Biringer1, Ján Danko1 \\ ${ }^{1}$ Department of Obstetrics and Gynecology, Jessenius Faculty of Medicine, Comenius University in Bratislava, \\ Martin, Slovakia \\ ${ }^{2}$ Hemathology and Transfusiology Clinics, Jessenius Faculty of Medicine, Comenius University in Bratislava, \\ Martin, Slovakia \\ Email: petra.sumichrastova@gmail.com
}

Received 6 March 2014; revised 2 May 2014; accepted 17 May 2014

Copyright (C) 2014 by authors and Scientific Research Publishing Inc.

This work is licensed under the Creative Commons Attribution International License (CC BY). http://creativecommons.org/licenses/by/4.0/

\section{Open Access}

\begin{abstract}
Introduction: Based on many scientific research studies, there has been demonstrated a relation between smoking of pregnant women and its negative effects on pregnancy, intrauterine fetal growth, postnatal newborn condition, and development. The aim of our study is to highlight the adverse effects of cigarette use during pregnancy and to evaluate the effect of maternal smoking on the levels of erythropoietin (EPO) in umbilical cord plasma. Our aim was to show an effect of maternal smoking by determining carboxyhemoglobin ( $\mathrm{COHb}$ ) levels in maternal blood, too. Design: Prospective analysis. Setting: Department of Gynecology and Obstetrics, Jessenius Faculty of Medicine, Comenius University, Martin, Slovak Republic. Methods: Our study included 174 newborns. Mothers were divided into group of smokers $(n=67)$ and non-smokers $(n=107)$. This prospective study was realized from February 2012 to November 2013 at the Department of Gynecology and Obstetrics, Jessenius Faculty of Medicine in Martin, Slovak Republic. Patients signed a written informed consent and completed a questionnaire that involved medical history, and data of their smoking habits. EPO levels were measured in 174 samples of umbilical cord plasma. Infants were born spontaneously at term. Results: We observed significantly higher EPO levels in umbilical cord plasma in children born to smokers in contrast to non-smokers' (children of nonsmoking mothers: $19 \pm 8 \mathrm{mIU} / \mathrm{mL}$; children of smokers: $61 \pm 33 \mathrm{mIU} / \mathrm{mL}, \mathrm{p}<0.01$ ). The COHb levels were significantly higher in smokers (non-smokers: $0.8 \% \pm 0.4 \%$; smokers: $3.6 \% \pm 1.1 \%$, $p<$
\end{abstract}

*Corresponding author.

How to cite this paper: Šumichrastová, P., et al. (2014) Negative Effects of Maternal Smoking on Pregnancy and the Fetus in Relation to Elevated Levels of Erythropoetin in Umbilical Cord Plasma. Open Journal of Preventive Medicine, 4, $307-316$. http://dx.doi.org/10.4236/ojpm.2014.45038 
0.001). Conclusion: Smoking during pregnancy is associated with elevated EPO concentrations in umbilical cord plasma at the time of birth. Based on the results of our study, we would like to support women planning pregnancy and pregnant women to quit smoking. Closer surveillance is recommended in smoking pregnant women, particularly because of the risk of placental insufficiency and fetal growth retardation.

\section{Keywords}

\section{Maternal Smoking, Pregnancy, Erythropoetin, Carboxyhemoglobin, Umbilical Cord}

\section{Introduction}

According to a large number of publications the association between smoking in pregnancy and its negative influence on gravidity, fetal growth, post-delivery adaptation and subsequent newborn's well-being was proved. High levels of carbone oxide (CO) in cigarette smoke can cause impairment of fetal and maternal condition. Carboxyhemoglobine present in smoking pregnant women is responsible for decreased oxygen transport and causes fetal hypoxia. Nicotine narrows the vessels and decreses uterine blood flow. The "fetal" side of placenta is characterized by $15 \%$ higher nicotine concentration in comparison to the "maternal" side. Cotinine (the key nicotine metabolite) is present in urine, hair and also in saliva of smokers' neonates [1].

Smoking during pregnancy causes severe metabolic, biochemical changes and adaptive response in fetuses leading to increased incidence of maternal and fetal complications: preterm labour, premature rupture of membranes, extrauterine gravidity (GEU), placental complications, spontaneous abortions, intrauterine fetal death, sudden newborn death syndrome, low neonatal birth weight, low Apgar scores, intrauterine fetal growth retardation, the "fetal tobacco syndrome" and long-term chronical complications [2]-[7].

Erytropoetin (EPO) is a glycoprotein hormone and a primar erytropoesis regulator which stimulates proliferation and differentiation of precursor erytroid cells in bone marrow. EPO regulates the red blood cells creation to cover the tissues needs for oxygen, the only known stimulation for the EPO production is hypoxia [8]. EPO doesn't transfer the placenta, it has no reserve form and its origin in umbilical blood is fetal. Elevated EPO levels were assessed in pregnancies complicated by preeclampsia, diabetes, fetal macrosomia, presence of meconium in amniotic fluid, Rh-isoimunisation, intrauterine fetal growth restriction, maternal smoking and alcohol consumpsion, fetal anaemia and haemorrhage [9] [10]. The main goal of our study was to observe the effect of maternal cigarette smoking on consequential EPO umbilical plasmatic levels and compare them with the levels in non-smoking mothers. We assumed that maternal smoking during pregnancy can cause fetal hypoxia associated with elevated EPO levels, which turns out to be a chronic intrauterine hypoxia marker according to several studies.

\section{Materials and Method}

The study protocol was approved by Ethical Committee of Jessenius Faculty of Medicine in Martin (No. EK 1034/2012). We included 174 newborns in our study. Mothers were divided in 67 active smokers and 107 non-smokers. This prospective study was realised from February 2012 to November 2013 in the Department of Obstetrics and Gynecology in University Hospital Martin, Slovakia. The group of non-smoking mothers never smoked actively and was never exposed to passive smoking.

All women subscribed the informed consent before being included in the study and they fulfilled the following criteria: 1) vaginal delivery, 2) no severe disease in personal history, 3) absence of arterial hypertension and diabetes in personal history, 4) no pregnancy complications, 5) intrauterine fetal growth restriction absence, 6) clear amniotic fluid withouth the presence of meconium, 7) gestational age from 37th to 42nd gestational week according to late menstruation period and first-trimester ultrasound examination, 8) the smoking pregnant women consumed cigarettes actively before and also during the pragnancy, 9) singleton gravidity, 10) compatible birth weight and gestational age.

A partial goal of our study was to compare subsequent parameters in the group of smokers and non-smokers: 1) maternal age, 2) the number of sponatneous abortions and GEU in anamnesis, 3) total number of gravidities 
and parity, 4) gestational age at delivery, 5) neonates' birth weight and lenght, 6) the Apgar score in 1st, 5th and 10th minute after delivery, 7) the number of cigarettes daily smoked before the gravidity, 8) the number of cigarettes daily smoked during gravidity, 9) number of nicotine-abuse years.

After the spontaneous vaginal delivery cca $15 \mathrm{~cm}$ long segment of the umbilical cord was clemmed on two places ans subsequently cut before the newborn's first inspirium. The umbilical blood was withdrawn from umbilical artery (UA) and umbilical vein (UV) for the assessment of laboratory parameters. The venous blood was withdrawn till the complete collaps of UV to avoid the possibillity of artifitial mixture of venous and arterial blood. We performed the punction of UA subsequently. The samples for the EPO level assessment from UV were transported in EDTA tubes to the laboratory of Clinics of Haemathology and Transfusiology of JLF UK in 30 minutes from withdrawal. The plasma has been separated by centrifugation for 15 minutes at 2100 rounds per minute (RPM) and stored at $-80^{\circ} \mathrm{C}$. For the analysis diagnostic Quantikine ${ }^{\circledR}$ IVD ${ }^{\circledR}$ ELISA, Human Erythropoetin Immunoassay (USA \& Canada R \& D Systems, Inc.) set was used.

For the EPO levels assessment all the reagences and samples were tempered for the room temperature $\left(20^{\circ} \mathrm{C}\right.$ $25^{\circ} \mathrm{C}$ ). We pipetted $100 \mu \mathrm{L}$ of EPO assay diluent into every micro-titration hole. We added $100 \mu \mathrm{L}$ of standard solution in 4 holes for the calibration curve preparation, one was used for control and the samples were pipetted in the residual holes. We have vibrated the micro-titration plate very softly for one minute after the incubation in darkness at room temperature for 2 hours \pm 5 minutes. Subsequntly the content of every hole was sucked very thoroughly. We added $200 \mu \mathrm{L}$ of EPO conjugate in every hole and incubated again under the same conditions (in darkness at room temperature for 2 hours \pm 5 minutes). Then we have sucked every hole and performed the washing four times. The resting solution was removed after this procedure. $200 \mu \mathrm{L}$ of substrate was added to every hole (the substrate was used maximally 15 minutes after the preparation), we have incubated the samples for 20 - 25 minutes at room temperature. After adding $100 \mu \mathrm{L}$ of stop solution we subtrackted the optical density (OD) at $450 \mathrm{~nm}$.

Other part of our research was to collect maternal venous blood from v. cubiti to assess the hemoglobine (Hb) and carboxyhemoglobine $(\mathrm{COHb})$ levels. We evaluated also the values of $\mathrm{pH}, \mathrm{pO}_{2}, \mathrm{pCO}_{2}$ and $\mathrm{COHb}$ in blood samples from UV and UA. We collected the blood into heparinized capillaries. Above mentioned parameters were analysed on Rapidlab® ${ }^{\circledR}$ 1265, Siemens Healthcare Diagnostics, New York, USA.

All the results were statistically analysed using IBM ${ }^{\circledR}$ SPSS ${ }^{\circledR}$ Statistics 17 software. We compared the average values in smoking and non-smoking group using the student t-test and corellations were evaluated by regression analysis. The data were enregistered as average value \pm standard deviation (SD). Statistically significant differences were defined as $\mathrm{p}<0.05$.

\section{Results}

Non-smoking mothers' average age at the time of delivery was $29 \pm 5$ years in comparison to smokers who were younger ( $27 \pm 6$ years at the time of delivery) (Table 1 ). Smoking mothers consumed daily $7 \pm 4$ cigaretes during and $17 \pm 11$ cigarettes daily before the pregnancy, the average years of nicotine abuse was $9 \pm 5$ (Table 5). Both groups had similar average number of gravidities, parity and the lenght of gestation (Table 1). Number of spontaneousabortions was similar in both groups. We noted two cases of ectopic pregnancy in the non smokers group in contrary to smokers where this pathology did not occur (Table 1). The neonate's of smoking mothers Apgar scores in the 1st minute were lower in comparison to non-smoker neonates but in 5th and 10th minute the Apgar scores were similar in both groups (Table 2). The smoker's neonates had in average $221 \mathrm{~g}$ lower gestational weight, in fact, there was no significant difference in neonate's lenght in both groups (Table 2). The umbilical plasmatic EPO levels were significantly elevated in smoker's neonates compared to non smoker's neonates (Table 2, Figure 1). The result of our study is significantly positive correlation between the number of cigarettes daily smoked before the gravidity and umbilical plasmatic EPO levels $(\mathrm{p}<0.01)$. Similarly, there was a positive correllation assessed between the umbilical plasmatic EPO levels and the number of cigarettes daily consumed during pregnancy ( $\mathrm{p}<0.001$ ). There was no significantly positive statistical correlation between EPO levels and overall years of nicotine abuse (Table 5). We noted significant continual proportion between the EPO and COHb umbilical levels ( $\mathrm{p}<0.001$ ). The $\mathrm{pH}, \mathrm{pO}_{2}, \mathrm{pCO}_{2}$ a COHb levels in UA and UV in smoker's and nonsmokers' neonates are concluded in Table 3 and in Figure 2 and Figure 3. We do not report significant differences of hemoglobine levels between smokers and non-smokers group in our study. The COHb values were statistically significant higher in smokers (Table 4). 
Table 1. Comparison of smoking and non smoking mothers*'.

\begin{tabular}{cccc}
\hline & Non-smokers & Smokers & $\mathrm{p}^{\circ}$ \\
\hline Number of subjects & 107 & 67 & \\
Maternal age (years) & $29 \pm 5$ & $27 \pm 6$ & NS \\
Number of gravidities & $2.1 \pm 1.1$ & $2.3 \pm 1.9$ & NS \\
Parity & $1.7 \pm 0.9$ & $2 \pm 1.7$ & NS \\
Spontaneous abortions & $0.19 \pm 0.4$ & $0.2 \pm 0.4$ & NS \\
Extrauterine gravidities & 2 & 0 & NS \\
Gestational age & $40 \pm 1$ & $40 \pm 1$ & NS \\
\hline
\end{tabular}

*The data recorded as average values (mean) \pm standard deviation (SD) or number $(\mathrm{n}) .{ }^{\circ} \mathrm{NS}=$ non-significant $(\mathrm{p}>0.05)$.

Table 2. Maternal smoking and neonatal outcome associations*.

\begin{tabular}{cccc}
\hline & Non-smokers & Smokers & $\mathrm{p}^{\circ}$ \\
\hline Number of subjects & 107 & 67 & \\
Apgar score & & & \\
1 minute & $9 \pm 0.4$ & $8.7 \pm 1$ & 0.029 \\
5 minute & $9.2 \pm 0.4$ & $9.1 \pm 0.8$ & NS \\
10 minute & $9.4 \pm 0.5$ & $9.4 \pm 0.6$ & NS \\
Fetal weight (g) & $3472.9 \pm 435.6$ & $3251.9 \pm 422.2$ & 0.041 \\
$\begin{array}{c}\text { Neonates' lenght (cm) } \\
\text { Erytropoetin levels } \\
\text { (mIU/mL) }\end{array}$ & $51.2 \pm 1.9$ & $50.5 \pm 2.1$ & NS \\
\hline
\end{tabular}

${ }^{*}$ The data recorded as average values (mean) \pm standard deviation (SD) or number (n). ${ }^{\circ} \mathrm{NS}=$ non-significant $(\mathrm{p}>0.05)$.

Table 3. The smoking in pregnancy and the neonatal risks*.

\begin{tabular}{cccc}
\hline & Non-smokers & Smokers & $\mathrm{p}^{\mathrm{o}}$ \\
\hline Number of subjects & 107 & 67 & \\
Umbilical cord blood & & & \\
$\mathrm{pH}$ in a. umbilicalis & $7.31 \pm 0.05$ & $7.3 \pm 0.05$ & 0.001 \\
$\mathrm{pH}$ in v. umbilicalis & $7.37 \pm 0.05$ & $7.35 \pm 0.05$ & 0.012 \\
$\mathrm{pO}_{2}$ in a. umbilicalis $(\mathrm{kPa})$ & $2.4 \pm 0.56$ & $2.19 \pm 0.69$ & 0.004 \\
$\mathrm{pO}_{2}$ in v. umbilicalis $(\mathrm{kPa})$ & $3.8 \pm 0.93$ & $3.73 \pm 1.08$ & 0.004 \\
$\mathrm{pCO}_{2}$ in a. umbilicalis $(\mathrm{kPa})$ & $6.4 \pm 0.95$ & $6.7 \pm 1.12$ & 0.003 \\
$\mathrm{pCO}_{2}$ in v. umbilicalis $(\mathrm{kPa})$ & $5.1 \pm 0.94$ & $5.28 \pm 1.11$ & 0.002 \\
$\mathrm{COHb}$ in a. umbilicalis (\%) & $0.7 \pm 0.5$ & $3.6 \pm 1.1$ & $\mathrm{p}<0.001$ \\
$\mathrm{COHb}$ in v. umbilicalis $(\%)$ & $1.1 \pm 0.5$ & $3.7 \pm 1.2$ & $\mathrm{p}<0.001$ \\
\hline
\end{tabular}

*The data recorded as average values (mean) \pm standard deviation (SD). ${ }^{\circ} \mathrm{NS}=$ non-significant $(\mathrm{p}>0.05)$. 
Table 4. Hemoglobine and carboxyhemoglobine levels in smoking and non-smoking pregnant women**

\begin{tabular}{cccc}
\hline & Non-smokers & Smokers & $\mathrm{p}^{\circ}$ \\
\hline Number of subjects & 107 & 67 & \\
Hemoglobine (g/L) & $125 \pm 11$ & $123 \pm 10$ & NS \\
Carboxyhemoglobine (\%) & $0.8 \pm 0.4$ & $3.6 \pm 1.1$ & $\mathrm{p}<0.001$ \\
\hline
\end{tabular}

*The data recorded as average values (mean) \pm standard deviation (SD). ${ }^{\circ} \mathrm{NS}=$ non-significant $(\mathrm{p}>0.05)$.

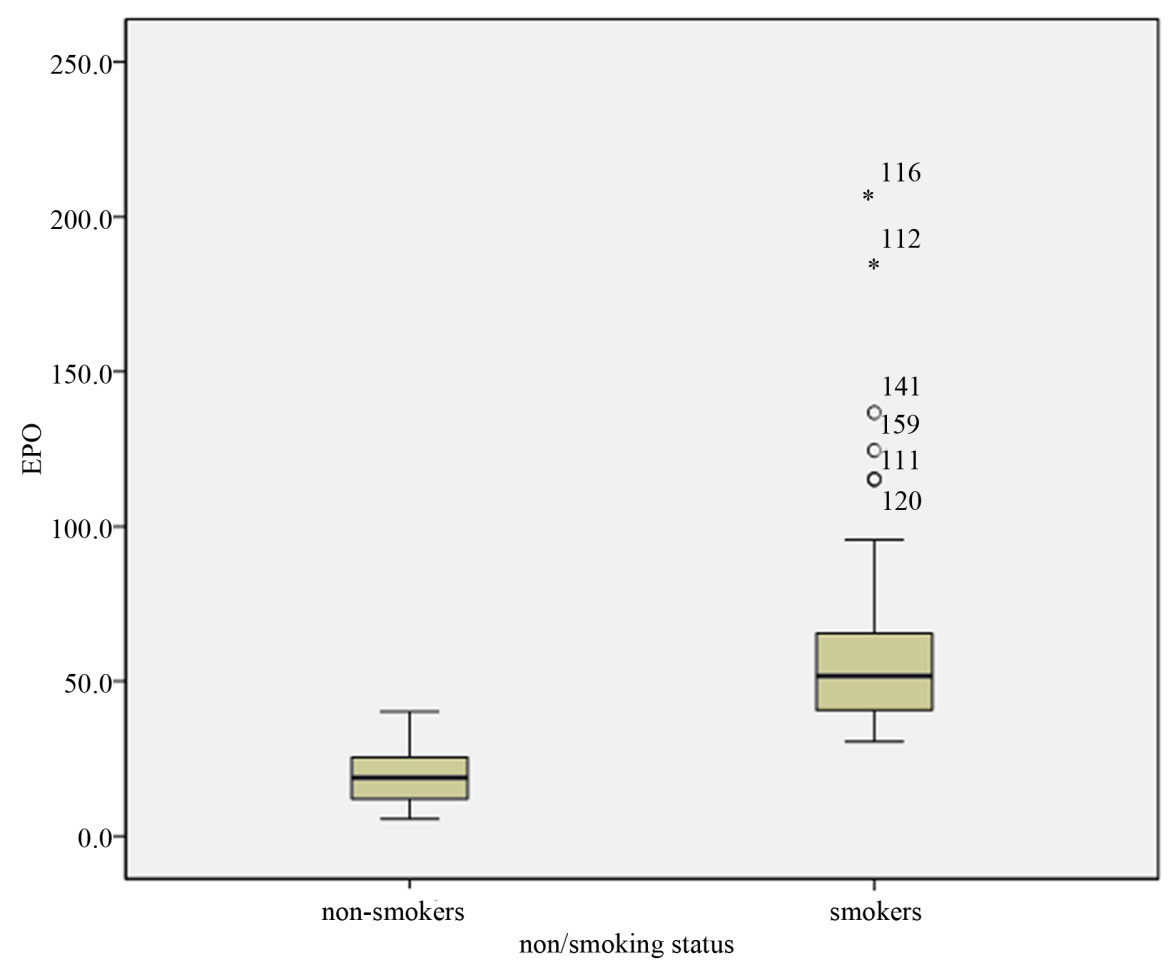

Figure 1. Erytropoetin levels (mIU/mL) according to smoking or non-smoking status.

\section{Discussion}

In our study smoking and non-smoking pregnant women with similar average number of gravidities, parity and the lenght of gestation were involved. There are miscellanous ethiologic factors leading to preterm pregnancy termination e.g. infection, several pathologies associated with obesity, inappropriate nutrition, alcohol and cigarette abuse and many others. Literary resources confirm more frequent preterm labours in smokers, while the relative risk arises from $36 \%$ to $47 \%$ and atributive risk from $11 \%$ to $14 \%$. Several studies reported the percentage of probability of preterm labour in "moderate" smokers from $1.3 \%$ to $1.4 \%$ and in "heavy" smokers from $1.6 \%$ to $1.8 \%$ [3].

Despite of the fact that smoking increases the risk of preterm labour, we involved in our study only women whose gestational age at the time of the pregnancy termination ranged from 37th to 42nd gestational week according to the late menstruation period and first trimester ultrasound.

The smoking is thought to be one of the predisposing risk factor for the development of extrauterine gravidity, it is believed its connection to the development of inflammation in pelvic region and via this fact to decrease the tubal transport. In several studies positive correlation between the amount of smoked cigarettes and their negative influence on extrauterine gravidity was reported [2]. We observed only two cases of GEU in the non-smokers group, no occurance in smokers' group. We therefore suppose that the occurance of the ectopic pregnancy can be much higher in a bigger cohort of smoking women. 


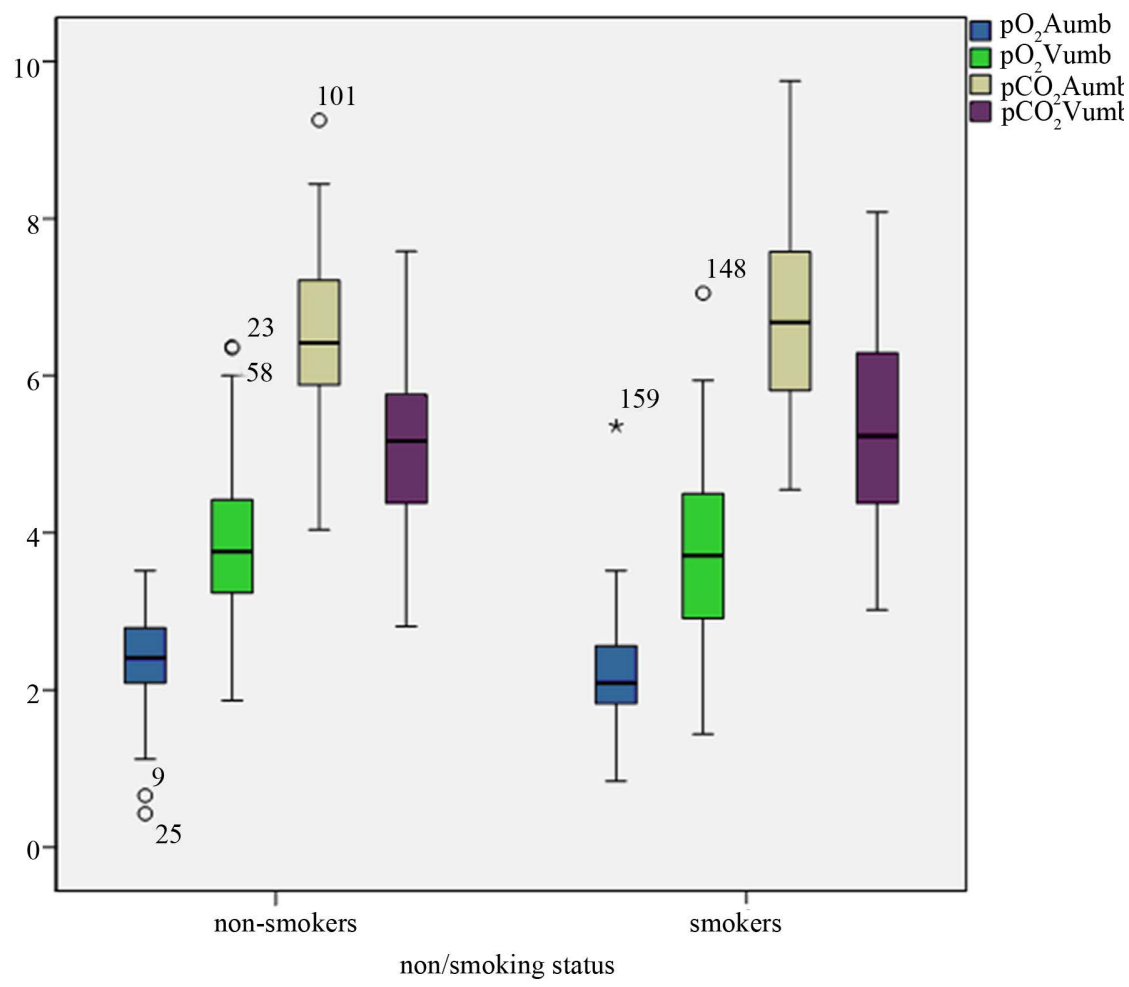

Figure 2. The graphical comparison of $\mathrm{pO}_{2}$ and $\mathrm{pCO}_{2}$ in a. and $\mathrm{v}$. umbilicalis in smoking and non-smoking mothers.

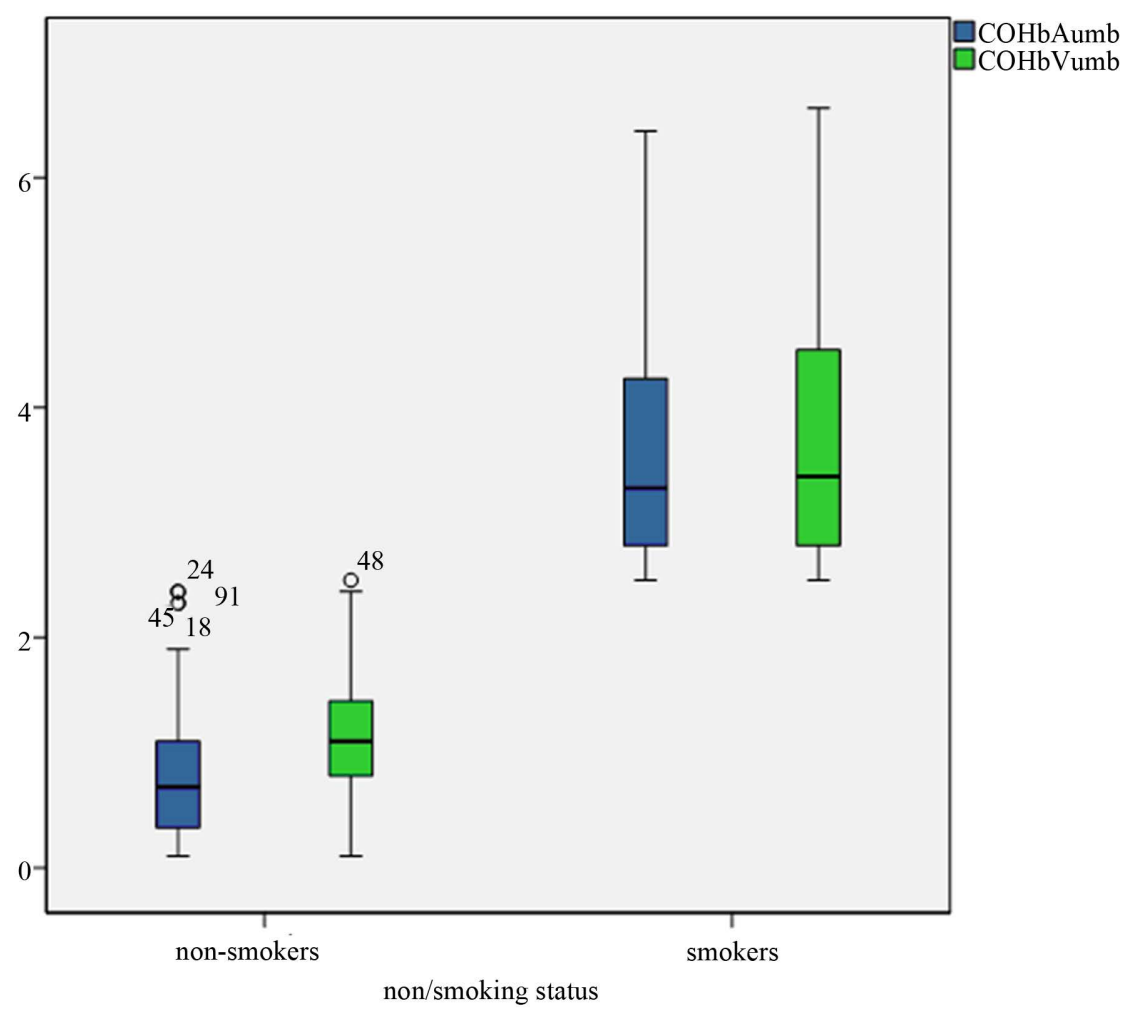

Figure 3. Graphical comparison of $\mathrm{COHb}(\%)$ in a. and v. umbilicalis smoking and non-smoking pregnant women. 
According to more reports a positive association between cigarette smoking and increased spontaneous abortion risk was assessed. These works assume a higher risk of spontaneous abortion in women smoking from 10 to 19 cigarettes, or more than 20 per day [11]. Toxines in cigarette smoke which influence the viability of gametes, premature embryonic division, the embryo transport and its implantation can cause complications and premature termination of pregnancy. When comparing the number of spontaneous abortions in our groups we assessed higher frequency in smoker's group in comparison to control group, but the difference was not significant.

The harmful effects of cigarette smoke on the neonate's birth weight are denoted as "fetal tobacco syndrome"-it was described in smoking mothers who consume 5 and more cigarettes per day. In smoking mothers a 2-fold higher low birth weight risk $(<2500 \mathrm{~g})$ was reported. Neonates of smokers who consume tobacco actively throughout gravidity are weighing approximately $200 \mathrm{~g}$ less and are $1.4 \mathrm{~cm}$ "shorter" than neonates of non-smoking women. In our study we confirmed this data, whereas we assessed 221 lower smoking mother neonates birth weight and these children were in average $0.7 \mathrm{~cm}$ "shorter" than non-smoker's neonates. According to Wang et al. (2002) the existence of genetic factors could modify the risk connected with cigarette smoking and decreased birth weight. Several studies reported a number of maternal genotypes probably connected with nicotine abuse and neonate's birth weight decrease. These authors assume existence of interactions between nicotine abuse and metabolic genes in association with fetal growth. Bergsjø, Bakketeig and Lindmark (2007) declared the effect of nicotine abuse on fetal growth retardation (the tobacco syndrome respectively) in the second half of pregnancy on the basis of several pathophysiological mechanisms [12]. The pathogenesis of low birth weight is not precisely defined eventhough it is supposed that it is multifactorial. One of the possible mechanisms is $\mathrm{COHb}$ production in maternal and fetal circulation, what affects decrease of the oxygen transfer and leads to tissue hypoxia and increased viscosity. This leads to the negative effect on placental perfusion. Cyanide in cigarette smoke can decrease the vitamine B12 (very important fetal growth co-factor) reserves.

Aycicek et al. (2011) examined the influence of active and passive maternal cigarette smoking on overall oxidative/antioxidative placental status in children delivered on term. The birth weight and the head circumference in children of smoking mothers were significantly decreased in comparison to control group of nonsmoking mother's neonates $(\mathrm{p}<0.001)$. The overall antioxidative capacity in placenta, umbilical cord and maternal peripheral blood was significantly decreased in active smokers in comparison to non-smokers ( $<<$ 0.001 ), whereas the oxidative stress index values were statistically significant higher in active and passive smokers in comparison to non-smoking mothers $(\mathrm{p}<0.001)$. In conclusion the authors assume that active and also passive maternal smoking is associated with significant changes in the equilibrium of oxidative and antioxidative status of placental tissue and is the cause of oxidative stress [13].

In our study we assessed significantly higher EPO levels in umbilical plasma in children of smoking mothers compared to non-smokers' children (Table 2, Figure 1). These results are consistent with hypothesis of maternal smoking as a cause of fetal hypoxia and potentional fetal complication occurance [4] [5] [7] [10]. The result of our study was a significantly positive correlation between the number of cigarettes smoked daily before gravidity and umbilical plasma EPO level $(\mathrm{p}<0.01)$, moreover we assessed a gignificant positive correlation of EPO umbilical plasma levels with the number of cigarettes consumed during pregnancy $(\mathrm{p}<0.001)$. The correlation between the duration of nicotine abuse in years and EPO umbilical plasma levels was not significant (Table 5). We noted significant continual proportion between the EPO and COHb umbilical levels $(\mathrm{p}<0.001)$. In our work we also noted differences in $\mathrm{pH}, \mathrm{pO}_{2}, \mathrm{pCO}_{2}$ a $\mathrm{COHb}$ in UA and UV concentrations in newborns of smoking and non-smoking mothers (Table 3, Figure 2 and Figure 3).

Eventhough the examination of acidobase parameters remains the golden standard of biochemical intrauterine fetal condition diagnosis, clinical and scientific afford leads to the search for new, more valid biochemical markers, able to eliminate the fetal affection by hypoxemic-ischemic insult. There is a plenty of studies examining new parameters these days. Authors reviewing the validity of biochemical diagnostic methods for fetal hypoxia, namely $\mathrm{pH}$, base excess, lactate, EPO and S100B protein confirmed the fact of significantly elevated EPO levels in UV plasma in fetal hypoxia occurance. The fetal EPO UV plasma levels in the studied group correlated significantly in inversed proportionality with UA pH $(\mathrm{p}<0.05)$ as well as with base excess $(\mathrm{p}<0.05)$ [14]. The EPO levels are elevated already due to vaginal delivery, what could represent certain fetal adaptation mechanism, whereby there was no striking elevation of EPO production in elective caesarean section deliveries observed.

On the basis of several studies the inversed proportionality of EPO levels during the delivery correlated to $\mathrm{pH}$, 
Table 5. Correlation between EPO level and the number of cigarettes smoked daily before and during the pregnancy, correlation between EPO and $\mathrm{COHb}$ levels ${ }^{*}$.

\begin{tabular}{lcc}
\hline & EPO level in smokers $(\mathrm{n}=67) 61 \pm 33(\mathrm{mIU} / \mathrm{mL})$ & $\mathrm{p}^{\circ}$ \\
\hline $\begin{array}{c}\text { Number of cigarettes smoked } \\
\text { daily during the pregnancy }\end{array}$ & $7 \pm 4$ & $\mathrm{p}<0.001$ \\
$\begin{array}{c}\text { Number of cigarettes smoked } \\
\text { daily before the pregnancy } \\
\text { Years of smoking }\end{array}$ & $17 \pm 11$ & $\mathrm{p}<0.01$ \\
$\begin{array}{l}\text { COHb in a. umbilicalis (\%) } \\
\text { COHb in v. umbilicalis (\%) }\end{array}$ & $9 \pm 5.6 \pm 1.1$ & $\mathrm{NS}$ \\
\hline${ }^{*}$ The data recorded as average values (mean) \pm standard deviation (SD) ${ }^{\circ} \mathrm{NS}=$ non-significant $(\mathrm{p}>0.05) .001$
\end{tabular}

$\mathrm{pO}_{2}$ and base excess in UA and a continual proportion with $\mathrm{pCO}_{2}$, amniotic fluid with meconium and lactate levels was confirmed.

Two studies affirmed the correlation between fetal hypoxia and elevated EPO levels in umbilical cord blood, but the small for gestational age (SGA) newborns were included in this study and, apparently, the fetal growth restriction can influence the EPO levels [15]. In another study involving SGA newborns noted elevated EPO levels in smoking mothers' newborns, whereby the number of cigarettes smoked daily correlated with EPO levels [5]. Similarly to authors of a recent study we involved in our research cohort only newborns with weight concordant to their gestational age, to eliminate the influence of other possible toxic effect probably leading to hypoxia formation [9]. According to these facts the results of our study are more capable to reflect the effect of smoking on EPO levels elevation in comparison to previous publications. Account on this we conclude that cigarette smoking has negative effect in the meaning of chronic fetal hypoxia and this dangerous influence of cigarette abuse correlates with the doses. These findings are in concordance with the results of previous studies [4] [5] and explain available information about the risk of cigarette abuse in pregnancy. Part of our study was also the examination of $\mathrm{COHb}$ levels in mothers as a "smoking" marker leading to objectivisation of questionnaire data about nicotine abuse. The COHb levels were statistically significantly elevated in smokers (Table 4). The correlation between the number of cigarettes smoked daily before and during the pregnancy and $\mathrm{COHb}$ levels in smokers was in significant continual proportion ( $\mathrm{p}<0.001)$. Other authors studying negative influence of maternal passive or active smoking on the pragenancy examined the relation between the cotinine levels and the number of cigarettes consumed daily in pregnancy assessed significantly continual proportion [16]-[21].

Fetal hypoxia stimulates the EPO synthesis what could be caused by several mechanisms. Nicotine affects the cardiovascular system by releasing the catecholamines to mothers' blood circulation, subsequently tachycardia, periferal vasoconstriction, and the reduction of placental blood flow occurs. Decrease of placental blood flow can cause inefficient nutrition and oxygenation decrease for the fetus. Cotinine (the nicotine metabolite) increases vasoconstrictive prostaglandine E2 effect and accumulation of cotinine in fetal blood circulation can contribute to preterm labour or spontaneous abortion in smoking pregnant women. CO originating from the cigarette burning has a very strong afinity to fetal $\mathrm{Hb}$ what leads to hypoxia in the fetus. Recently, a strong positive correlation was proved in number of cigarettes smoked per day and the absolute erythrocyte number (as another chronic hypoxia marker), what can clarify higher Hb levels in smoking mothers newborns [10].

Suboptimal fetal oxygenation can cause several perinatal complications in fetuses of smoking mothers. CO can interfere with tissue oxygenation via descreasing the transport capacity for blood oxygen, the oxyhemoglobine saturation curve is shifted to the left and this leads to hypoxemia associated with growth restriction. The smokers have also insufficient amount of several nutrients e.g. Zn, carotene and cholesterol. Several studies point to mechanisms associated with chronic fetal hypoxia contributing pathogenesis of spontaneous abortion, preterm labour, placenta praevia, placental abruption, intrauterine growth restriction, sudden newborns'death syndrome, mild brain dysfunction, increased perinatal mortality, congenital anomalies and malignancies [6]. The risk of perinatal and obstetrical problems depends on the number of cigarettes smoked daily and from the trimester with the highest exposure. The cigarette smoke components cross the placenta whereby changes in oxygen transport, placental and maternal metabolism occur on behalf of smoking [4] [10] [22]. 


\section{Conclusions}

Authors of this study, dealing the negative effects of maternal smoking on pregnancy and the fetus, acertained significantly elevated EPO umbilical plasma levels in smoking mothers' newborns in contrast to non-smoking mothers' newborns. The smoking mothers' newborns in the studied group had a lower birth weight in average and lower Apgar scores in comparison to non-smoking mothers' newborns. Our results are in concordance with hypothesis that assuming the nicotine abuse in pregnant women can cause fetal hypoxia and potentional fetal complications occurance.

On the ground of results of this study we would like to support women planning gravidity to quit smoking before the beginning of gravidity. We think that a smoking pregnant woman should be monitored more frequently because of the elevated risk of placental insufficiency and fetal growth restriction development. We are convinced that decreasing the negative risk factors influencing pregnancy including the nicotine abuse, as well as education in this field are substantiated.

\section{Acknowledgements}

This work was supported by the project "Centre of excellence for perinatology research (CEPV I)", ITMS: 26220120016, co-financed by EU grants, by the project "Centre of excellence for perinatology research establishment (CEPV II)”, ITMS: 26220120036, co-financed by EU grants, University grant UK/116/2013, project APVV-0315-11 and project VEGA MŠ1/0243/12.

\section{References}

[1] Hrubá, D. (2007) Proč nekouřit v těhotenství-Nové poznatky o účincích nikotinu. Praktická Gynekologie, 11, 132134.

[2] Bouyer, J., Coste, J., Shojaei, T., Pouly, J.L., Fernandez, H., Gerbaud, L. and Job-Spira, N. (2003) Risk Factors for Ectopic Pregnancy: A Comprehensive Analysis Based on a Large Case-Control, Population-Based Study in France. American Journal of Epidemiology, 3, 185-194. http://dx.doi.org/10.1093/aje/kwf190

[3] Burguet, A., Kaminski, M., Abraham-Lerat, L., Schaal, J.P., Cambonie, G., Fresson, J., Grandjean, H., Truffert, P., Marpeau, L., Voyer, M., Rozé, J.C., Treisser, A. and Larroque, B. (2004) The Complex Relationship between Smoking in Pregnancy and Very Preterm Delivery. Results of the Epipage Study. BJOG, 3, 258-265. http://dx.doi.org/10.1046/j.1471-0528.2003.00037.x

[4] Gruslin, A., Perkins, S.L., Manchanda, R., Fleming, N. and Clinch, J.J. (2000) Maternal Smoking and Fetal Erythropoietin Levels. Obstetrics \& Gynecology, 4, 561-564. http://dx.doi.org/10.1016/S0029-7844(99)00622-5

[5] Jazayeri, A., Tsibris, J.C.M. and Spellacy, W.N. (1998) Umbilical Cord Plasma Erythropoietin Levels in Pregnancies Complicated by Maternal Smoking. American Journal of Obstetrics \& Gynecology, 3, 433-435. http://dx.doi.org/10.1016/S0002-9378(98)70415-6

[6] Nakamura, M.U., Alexandre, S.M., Kuhn dos Santos, J.F., de Souza, E., Sass, N., Auritscher Beck, A.P., Trayna, E., Andrade, C.M., Barroso, T. and Kulay Júnior, L. (2004) Obstetric and Perinatal Effects of Active and/or Passive Smoking during Pregnancy. Sao Paulo Medical Journal, 3, 94-98.

[7] Ostlund, E., Lindholm, H., Hemsen, A. and Fried, G. (2000) Fetal Erythropoietin and Endothelin-1: Relation to Hypoxia and Intrauterine Growth Retardation. Acta Obstetricia et Gynecologica Scandinavica, 4, 276-282. http://dx.doi.org/10.1080/j.1600-0412.2000.079004276.x

[8] Kowalska-Kańka, A., Maciejewski, T. and Niemiec, K.T. (2013) The Role and Regulation of Secretion of Erythropoietin in Pregnancy. Medycyna Wieku Rozwojowego, 3, 270-275.

[9] Sazak, S., Kayıran, S.M. and Paksoy, Y. (2012) Umbilical Cord Serum Erythropoietin Levels and Maternal Smoking in Pregnancy. Scientific World Journal, 2012, Article ID: 420763. http://www.hindawi.com/journals/tswj/2012/420763/ http://dx.doi.org/10.1100/2012/420763

[10] Teramo, K.A. and Widness, J.A. (2009) Increased Fetal Plasma and Amniotic Fluid Erythropoietin Concentrations: Markers of Intrauterine Hypoxia. Neonatology, 2, 105-116. http://dx.doi.org/10.1159/000153094

[11] Wisborg, K., Kesmodel, U., Henriksen, T.B., Hedegaard, M. and Secher, N.J. (2003) A Prospective Study of Maternal Smoking and Spontaneous Abortion. Acta Obstetricia et Gynecologica Scandinavica, 10, 936-941. http://dx.doi.org/10.1034/j.1600-0412.2003.00244.x

[12] Bergsjø, P., Bakketeig, L.S. and Lindmark, G. (2007) Maternal Smoking Does Not Affect Fetal Size as Measured in the Mid-Second Trimester. Acta Obstetricia et Gynecologica Scandinavica, 2, 156-160. 
http://dx.doi.org/10.1080/00016340600984696

[13] Aycicek, A., Varma, M., Ahmet, K., Abdurrahim, K. and Erel, O. (2011) Maternal Active or Passive Smoking Causes Oxidative Stress in Placental Tissue. European Journal of Pediatrics, 5, 645-651. http://dx.doi.org/10.1007/s00431-010-1338-9

[14] Biringer, K., Danko, J., Dókus, K., Mat’asová, K., Zibolen, M. and Pullmann, R. (2011) Biochemické aspekty fetálnej hypoxie. Ceská Gynekologie, 4, 285-291.

[15] Bili, H., Mamopoulos, M., Tsantali, C., Tzevelekis, P., Malaka, K., Mantalenakis, S. and Farmakides, G. (1996) Elevated Umbilical Erythropoietin Levels during Labor in Newborns of Smoking Mothers. American Journal of Perinatology, 2, 85-87. http://dx.doi.org/10.1055/s-2007-994298

[16] Andersen, S.L., Nøhr, S.B., Wu, C.S., Olsen, J., Pedersen, K.M. and Laurberg, P. (2013) Thyroglobulin in Smoking Mothers and Their Newborns at Delivery Suggests Autoregulation of Placental Iodide Transport Overcoming Thiocyanate Inhibition. European Journal of Endocrinology, 5, 723-731. http://dx.doi.org/10.1530/EJE-12-0759

[17] Baheiraei, A., Banihosseini, S.Z., Heshmat, R., Mota, A. and Mohsenifar, A. (2012) Association of Self-Reported Passive Smoking in Pregnant Women with Cotinine Level of Maternal Urine and Umbilical Cord Blood at Delivery. Paediatric and Perinatal Epidemiology, 1, 70-76. http://dx.doi.org/10.1111/j.1365-3016.2011.01242.x

[18] Berlin, I., Heilbronner, C., Georgieu, S., Meier, C. and Spreux-Varoquaux, O. (2010) Newborns’ Cord Blood Plasma Cotinine Concentrations Are Similar to That of Their Delivering Smoking Mothers. Drug and Alcohol Dependence, 2-3, 250-252. http://dx.doi.org/10.1016/j.drugalcdep.2009.10.008

[19] Chełchowska, M., Gajewska, J., Ambroszkiewicz, J., Blumska-Janiak, M., Maciejewski, T. and Laskowska-Klita, T. (2010) The Effect of Tobacco Smoking on Serum Concentration of IGF-I and Its Binding Proteins IGFBP-3 and IGFBP-4 in Pregnant Women. Przeglad Lekarski, 10, 893-896.

[20] Chełchowska, M., Jabłonka-Salach, K., Ambroszkiewicz, J., Maciejewski, T., Gajewska, J., Bulska, E., LaskowskaKlita, T., Leibschang, J. and Barciszewski, J. (2012) Effect of Cigarette Smoking on Blood Lead Levels in Pregnant Women. Medycyna Wieku Rozwojowego, 3, 196-204.

[21] Yang, J., Pearl, M., Jacob III, P., DeLorenze, G.N., Benowitz, N.L., Yu, L., Havel, C. and Kharrazi, M. (2013) Levels of Cotinine in Dried Blood Specimens from Newborns as a Biomarker of Maternal Smoking Close to the Time of Delivery. American Journal of Epidemiology, 11, 1648-1654. http://dx.doi.org/10.1093/aje/kwt182

[22] Steyn, K., de Wet, T., Saloojee, Y., Nel, H. and Yach, D. (2006) The Influence of Maternal Cigarette Smoking, Snuff Use and Passive Smoking on Pregnancy Outcomes: The Birth to Ten Study. Paediatric and Perinatal Epidemiology, 2, 90-99. http://dx.doi.org/10.1111/j.1365-3016.2006.00707.x 